\title{
European Surgical Research
}

No. 1

Original Papers

1 Prolonged Improvement of Total Pancreatic Allograft Function by Previous Intrathymic Bone Marrow Cell Injection in Rats Drevillon, C.; Elian, N.; Zinzindohoue, F.; Carnot, F.; Bailbe, D.; Cugnenc, P.-H.; Altman, J.-J. (Paris)

6 Correlation between Mononuclear Infiltration and Changes in VASP Phosphorylation Patterns after Heterotopic Cardiac Transplantation in the Rat

Deuse, T.; Lange, V.; Schrepfer, S.; Eigenthaler, M.; Walter, U.; Elert, O. (Würzburg)

14 Portal Flow Diversion Is Essential for Graft Survival in Canine Auxiliary Partial Orthotopic Liver Transplantation de Jonge, J.; Zondervan, P.E.; Kooi, P.P.M.; IJzermans, J.N.M.; Metselaar, H.J.; Tilanus, H.W. (Rotterdam)

22 Assessment of the Intestinal Permeability following Postoperative Chemotherapy for Human Malignant Disease Inutsuka, S.; Takesue, F.; Yasuda, M.; Honda, M.; Nagahama, S.; Kusumoto, H.; Nozoe, T.; Korenaga, D. (Fukuoka)

26 Repetitive Pneumoperitoneum with Ozonized Oxygen as a Preventive in Lethal Polymicrobial Sepsis in Rats

Schulz, S. (Marburg); Rodriguez, Z.Z. (Havana); Mutters, R. (Marburg); Menendez, S. (Havana); Bette, M. (Marburg)

35 Influence of Omentectomy on Peritoneal Defense Mechanisms in an Experimental Model of Intra-Abdominal Infection Agca, B.; Paksoy, M.; Polat, E.; Aksin, E.; Dirican, A.; Durgun, V.; Eren, D. (Istanbul)

41 Influence of the Platelet-Activating Factor Receptor Antagonist BB-882 on Intra-Abdominal Adhesion Formation in Rats Otcu, S.; Ozturk, H.; Aldemir, M.; Kilinc, N.; Dokucu, A.I. (Diyarbakır)

46 Reduction of Surgery-Induced Peritoneal Adhesions by Continuous Release of Streptokinase from a Drug Delivery System

Yagmurlu, A.; Barlas, M.; Gursel, I.; Gokcora, I.H. (Ankara)

50 Variations in Flow, Duration, and Concentration Do Not Change the Final Lung Concentration of Melphalan after Isolated Lung Perfusion in Rats

Romijn, S.; Hendriks, J.M.H.; Van Putte, B.P. (Antwerp); Guetens, G.; De Bruijn, E.A. (Leuven); Van Schil, P.E.Y. (Antwerp)

54 Histological and Immunohistochemical Study of the Bronchial Stump with Flap Coverage in an Animal Model

Carbognani, P.; Corradi, A.; Bobbio, A.; Cantoni, A.M.; Mazzei, M.; Pazzini, L.; Galimberti, A.; Rusca, M. (Parma)

Letter to the Editor

58 Quality of Life in Animals as a New Outcome for Surgical Research: G-CSF as a Quality of Life Improving Factor Scheingraber, S.; Scheingraber, T.; Hirner, A. (Bonn)

59 Reply

Bauhofer, A.; Celik, J.; Koller, M. (Marburg)
No. 2

Original Papers

61 Involvement of IL-18 and Soluble Fas in Patients with Postoperative Hepatic Failure

Nakae, H.; Zheng, Y.-J.; Wada, H.; Tajimi, K. (Akita); Endo, S. (Morioka)

67 Hepatic Cryotherapy Involving the Vena cava. Experimental Study in a Pig Liver Model

Eggstein, S.; Neeff, H.; Szarzynski, M.; Jungraithmayr, W.; Haberstroh, J.; Kirste, G.; Schmitt-Graeff, A.; Farthmann, E.H. (Freiburg)

75 Acceleration of Gastric Ulcer Healing by Omeprazole in Porta Hypertensive Rats. Is Its Action Mediated by Gastrin Release and the Stimulation of Epithelial Proliferation?

Takeuchi, Y.; Kitano, S.; Bandoh, T.; Matsumoto, T.; Baatar, D.; Kai, S. (Oita)

81 Intravenously Administered Human Epidermal Growth Factor in the Rat. Biliary Excretion and Influences on Pancreatic Secretion

Jansen, C. (Lund); Nexo, E. (Aarhus); Ihse, I.; Axelson, J. (Lund)

86 Intra-Arterial Bone Marrow Cell Transplantation Induces Angiogenesis in Rat Hindlimb Ischemia

Yoshida, M.; Horimoto, H.; Mieno, S.; Nomura, Y.; Okawa, H.; Nakahara, K.; Sasaki, S. (Takatsuki)

92 Effects of Intra-Abdominal Drainages on Adhesion Formation and Prevention by Phospholipids in a Rat Model. Drainages and Adhesion Formation

Bertram, P.; Treutner, K.-H.; Tietze, L.; Vicas, M.; Weiss, C. (Aachen); Anurov, M.; Titkova, S.; Polivoda, M.; Oettinger, A.P. (Moscow); Schumpelick, V. (Aachen)

98 Testicular Blood Flow Alterations and Flow Cytometric Analysis in Prepubertal Rats with Experimentally Induced Unilateral Varicocele

Öztürk, H.; Surer, I.; Okur, H.; Demirbag, S.; Cetinkursun, S. (Ankara)

103 Percutaneous Peripheral Neuromodulation in the Treatment of Fecal Incontinence Shafik, A.; Ahmed, I. (Cairo); El-Sibai, O. (Shebin El-Kom); Mostafa, R.M. (Benha)

108 Left Ventricular Mechanical Unloading Restores Beta-2-Adrenergic Receptor mRNA Expression and Decreases Susceptibility to Ischemia and Reperfusion in the Failing Heart Nakahara, K.; Horimoto, H.; Nakai, Y.; Mieno, S.; Nomura, Y.; Sasaki, S. (Takatsuki)

115 Immunologic Effects of Allogeneic versus Autologous Blood Transfusion in Patients Undergoing Radical Oesophagectomy Takemura, M.; Osugi, H.; Takada, N.; Kinoshita, H.; Higashino, N. (Osaka)

Abstracts

123 Tumors of the Liver and Pancreas September 20-21, 2002, Dachau, Germany

Organizer and Guest Editor: Rau, H.-G. (Dachau)

141 Author Index for Abstracts

\section{KARGER}

Fax + 41613061234 E-Mail karger@karger.ch www.karger.com

\section{(C) 2003 S. Karger AG, Basel}

Access to full text and tables of contents, including tentative ones for forthcoming issues: www.karger.com/esr_issues 
No. 3

\section{Foreword}

38th Congress of the European Society for Surgical Research (ESSR)

Ghent, Belgium, May 28-31, 2003

de Hemptinne, B.; Ceelen, W.; Hesse, U.J. (Ghent)

Original Papers

143 Role of Oxygen Free Radical Scavengers in Acute Renal Failure Complicating Obstructive Jaundice

Kucuk, C.; Sozuer, E.; Ikizceli, I.; Avsarogullari, L.; Keceli, M.; Akgun, H.; Muhtaroglu, S. (Kayseri)

148 Hepatocyte Ploidy in Regenerating Livers after Partial Hepatectomy, Drug-Induced Necrosis, and Cirrhosis Gandillet, A.; Alexandre, E.; Royer, C.; Cinqualbre, J.; Jaeck, D. (Strasbourg); Richert, L. (Strasbourg/Besançon)

161 Mesh Implants in Hernia Repair. Inflammatory Cell Response in a Rat Model

Rosch, R.; Junge, K.; Schachtrupp, A.; Klinge, U.; Klosterhalfen, B.; Schumpelick, V. (Aachen)

Abstracts

167 38th Congress of the European Society for Surgical Research (ESSR)

Ghent, Belgium, May 28-31, 2003

Guest Editors: Ceelen, W.; de Hemptinne, B.; Hesse, U.J. (Ghent)

320 Author Index for Abstracts

No. 4

Original Papers

327 Identification of Differentially Expressed Genes Associated with Colorectal Cancer Liver Metastasis

Li, S.-R.; Dorudi, S.; Bustin, S.A. (London)

337 Determination of Regional Bone Blood Flow by Means of Fluorescent Microspheres Using an Automated SampleProcessing Procedure Anetzberger, H.; Thein, E.; Walli, A.K.; Messmer, K. (Munich)

346 Evaluation of a Preclinical Model of Bone Metastasis for the Study of Adoptive Immunotherapy

Rüttinger, D.; Li, R.; Urba, W.J.; Fox, B.A.; Hu, H.-M. (Portland, Oreg.)

352 Benefits of Intraluminal Injection of Glutamine for Intestinal Mucosa during Ischemia-Reperfusion

de Aguilar-Nascimento, J.E.; Gurgel Marques, C.; Carvalho Mariano, A.; Bicudo Salomão, A.; de Souza Neves, J. (Cuiabá)

357 Role of Granulocyte-Macrophage Colony-Stimulating Factor on Apoptosis Induced by Ischemia-Reperfusion in the Intestinal Epithelium

Bedirli, A.; Soyuer, I.; Muhtaroglu, S.; Guler, I. (Kayseri)

363 Evaluation of Quality in Patient-Controlled Analgesia Provided by an Acute Pain Service

Karcı, A.; Taşdöğen, A.; Erkin, Y.; Şahinöz, B.; Kara, H.; Elar, Z. (İzmir)

372 Experimental Study Using PTFE (Goretex) Patches for Replacement of the Oesophageal Wall

González Sáez, L.A.; Arnal Monreal, F.; Pita Fernández, S.; Machuca Santa Cruz, J. (La Coruña)

377 'On-Line' Alterations of Contralateral Jugular Blood Gas Profile during Carotid Clamping Vretzakis, G.; Papadimitriou, D.; Papaziogas, B.; Koutsias, S.; Christopoulos, D.; Ferdi, E. (Thessaloniki); Papadopoulos, G. (Ioannina)

383 Is Intraluminal Clip Application an Appropriate Treatment for latrogenic Gastric Perforation?

Karahasanoglu, T.; Altinli, E.; Hamzaoglu, I.; Aydogan, F.; Dobrucali, A. (Istanbul)
388 Omental Transposition Decreases Ischemic Brain Damage Examined in a New Ischemia Model

Vatansev, C.; Üstün, M.E.; Öğün, C.Ö.; Taştekin, G.; Karabacakoğlu, A.; Yilmaz, H. (Konya)

395 The Impact of Intestinal Ischaemia-Reperfusion on Caerulein Induced Oedematous Experimental Pancreatitis Farrant, G.J.; Abu-Zidan, F.M.; Liu, X. (Auckland); Delahunt, B. (Wellington); Zwi, L.J.; Windsor, J.A. (Auckland)

No. 5

Announcement

401 American Society for Stereotactic and Functional Neurosurgery Bestows Distinguished Service Award on Dr. med. h.c. mult. Thomas Karger and Prof. Dr. Phil Gildenberg

Original Papers

402 Pulmonary Microcirculation in Mild and Severe Experimental Pancreatitis

Kahrau, S.; Schneider, P.; Loddenkemper, C.; Buhr, H.J.; Foitzik, T. (Berlin)

408 Effects of Selective Cyclooxygenase Inhibitors on Ischemia/ Reperfusion-Induced Hepatic Microcirculatory Dysfunction in Mice

Ito, Y.; Katagiri, H.; Ishii, K.; Kakita, A.; Hayashi, I.; Majima, M. (Sagamihara)

417 Development of 'No-Reflow' Phenomenon in Ischemia/ Reperfusion Injury: Failure of Active Vasomotility and Not Simply Passive Vasoconstriction

Nanobashvili, J.; Neumayer, C.; Fuegl, A.; Blumer, R.; Prager, M.; Sporn, E.; Polterauer, P. (Vienna); Malinski, T. (Athens, Ohio); Huk, I. (Vienna)

425 Absence of a Relationship between the Increased Survival of Skin Grafts Provoked by Additional Spleen Transplantation and the Detection of Donor Chimeric Cells in Rats García-Olmo, D.C. (Albacete); García-Olmo, D. (Madrid); Ontañón, J.; Atiénzar, M.; García-Rivas, M. (Albacete)

430 A Rat Model for Severe Limb Ischemia at Rest Lundberg, G.; Luo, F.; Blegen, H.; Kalin, B.; Wahlberg, E. (Stockholm)

439 A Comparison of the Haemostatic Effect of Vivostat ${ }^{\circledR}$ Patient-Derived Fibrin Sealant with Oxidised Cellulose (Surgicel ${ }^{\circledR}$ ) in Multiple Surgical Procedures Hanks, J.B. (Charlotteville, Va.); Kjaergard, H.K. (Hellerup); Hollingsbee, D.A. (Deeside)

445 Vypro II $^{\circledR}$ Mesh in Hernia Repair: Impact of Polyglactin on Long-Term Incorporation in Rats

Rosch, R.; Junge, K. (Aachen); Quester, R. (Cologne); Klinge, U.; Klosterhalfen, B.; Schumpelick, V. (Aachen)

Short Communication

451 Perioperative Serum Procalcitonin Concentrations in Patients with Acute Aortic Dissection Kin, H.; Kawazoe, K.; Nakajima, T.; Niinuma, H.; Kataoka, T.; Endo, S.; Inada, K. (Morioka)

No. 6

Obituary

455 Prof. Dr. Roger Bénichoux 1919-2003

Original Papers

457 Linomide and Antibody-Targeted Superantigen Therapy Abolishes Formation of Liver Metastases in Mice

Liu, Q.; Klintman, D.; Corbascio, M.; Ekberg, H. (Malmö); Hedlund, G.; Forsberg, G. (Lund); Thorlacius, H. (Malmö) 
464 Receptor-Mediated Biphasic Alteration of Hepatocellular Transport from Hepatocyte to Bile Canaliculi as Measured by Near-Infrared Spectroscopy: A Novel Test with Glucagon for Biliary Excretion

Tanaka, A. (Maizuru); Shinohara, H. (Osaka); Yamaoka, Y. (Kyoto)

470 Prevention of Peritoneal Carcinomatosis from Human Gastric Cancer Cells by Adjuvant-Type Intraperitoneal Immunotherapy in a SCID Mouse Model

Piso, P.; Aselmann, H.; von Wasielewski, R. (Hannover); Dahlke, M.H. (Camperdown); Klempnauer, J. (Hannover); Schlitt, H.J. (Regensburg)

477 Minilaparotomy May Be Independently Associated with Reduction in Inflammatory Responses after Resection for Colorectal Cancer

Nakagoe, T.; Tsuji, T.; Sawai, T.; Sugawara, K.; Inokuchi, N.; Kamihira, S.; Arisawa, K. (Nagasaki)
486 Distance of Cecum Ligated Influences Mortality, Tumor Necrosis Factor-Alpha and Interleukin-6 Expression following Cecal Ligation and Puncture in the Rat Singleton, K.D.; Wischmeyer, P.E. (Denver, Colo.)

492 Serum and Drainage Fluid Vascular Endothelial Growth Factor Levels in Early Surgical Wounds

Karayiannakis, A.J. (Alexandroupolis); Zbar, A. (Bridgetown); Polychronidis, A. (Alexandroupolis); Simopoulos, C. (Bridgetown)

497 Persistent Extracellular Matrix Remodelling at the Interface to Polymers Used for Hernia Repair

Junge, K.; Rosch, R.; Bialasinski, L.; Klinge, U.; Klosterhalfen, B.; Schumpelick, V. (Aachen)

505 Author Index Vol. 35, 2003

507 Subject Index Vol. 35, 2003
S. Karger

Medical and Scientific Publishers

Basel $\cdot$ Freiburg $\cdot$ Paris $\cdot$ London

New York $\cdot$ Bangalore $\cdot$ Bangkok

Singapore $\cdot$ Tokyo $\cdot$ Sydney
Drug Dosage

The authors and the publisher have exerted every effort to ensure that drug selection and dosage set forth in this text are in accord with current recommendations and practice at the time of publication. However, in view of ongoing research, changes in government regulations, and the constant flow of information relating to drug therapy and drug reactions, the reader is urged to check the package insert for each drug for any chang in tic tions and dosege and for added warning an warnings and precautions. This is particularly important when the recommended agent is a new and/or infrequently employed drug.
All rights reserved.

No part of this publication may be translated into other languages, reproduced or utilized in any form or by any means, electronic or mechanical, including photocopying, recording microcopying, or by any information storage and retrieval system, without permission in writing from the publisher or, in the case of photocopying direct payment of a specified fee to the Copyright Clearance Center (see ‘General Information').

(c) Copyright 2003 by S. Karger AG,

P.O. Box, CH-4009 Basel (Switzerland)

Printed in Switzerland on acid-free paper by

Reinhardt Druck, Basel 